\title{
Quantitative Radiomic Features from Computed Tomography Can Predict Pancreatic Cancer up to 36 Months Before Diagnosis
}

Running title: Radiomic Features Predicts Pancreatic Cancer......

\section{Authors:}

Wansu Chen, $\mathrm{PhD}^{1}$, Yichen Zhou, $\mathrm{MS}^{1}$, Vahid Asadpour, $\mathrm{PhD}^{1}$, Rex A Parker, $\mathrm{MD}^{2}$, Eva Lustigova, $\mathrm{MPH}^{1}$, Eric J. Puttock, $\mathrm{PhD}^{1}$, Bechien U Wu, MD, $\mathrm{MPH}^{3}$.

\section{Affiliations:}

${ }^{1}$ Kaiser Permanente Southern California Research and Evaluation, Pasadena, CA

${ }^{2}$ Department of Radiology, Los Angeles Medical Center, Southern California Permanente Medical Group, Los Angeles, CA

${ }^{3}$ Center for Pancreatic Care, Department of Gastroenterology, Los Angeles Medical Center, Southern California Permanente Medical Group, Los Angeles, CA

Address where the work was conducted:

100 S Los Robles, 2nd Floor, Pasadena, CA 91101

\section{Correspondence:}

Wansu Chen, Ph.D.

Department of Research and Evaluation 
medRxiv preprint doi: https://doi.org/10.1101/2022.02.18.22271190; this version posted February 21, 2022. The copyright holder for this preprint

(which was not certified by peer review) is the author/funder, who has granted medRxiv a license to display the preprint in perpetuity.

All rights reserved. No reuse allowed without permission.

\section{Radiomic Features Predicts Pancreatic Cancer......}

Kaiser Permanente Southern California

100 S Los Robles, 2nd Floor, Pasadena, CA 91101

Email: Wansu.Chen@KP.org

Guarantor of the article: Dr. Wansu Chen is accepting full responsibility for the conduct of the study. She had access to the data and have control of the decision to publish.

Specific author contributions: Wansu Chen: Conceptualization, Methodology, Software, Validation, Investigation, Resources, Writing - original draft, Writing - review \& editing, Visualization, Supervision. Yichen Zhou: Methodology, Software, Validation, Formal analysis, Investigation, Data curation, Writing - review \& editing, Visualization. Vahid Asadpour: Methodology, Software, Formal analysis, Investigation, Data curation, Writing - review \& editing. Rex A Parker: Conceptualization, Methodology, Validation, Investigation, Data curation, Writing - review \& editing. Eva Lustigova: Conceptualization, Validation, Investigation, Writing - review \& editing, Supervision. Eric Puttock: Validation, Investigation, Writing - review \& editing. Bechien U Wu: Conceptualization, Methodology, Validation, Resources, Writing review \& editing, Supervision, Funding acquisition.

Financial support: Research reported in this publication was supported by the National Cancer Institute of the National Institutes of Health under Award Number R01CA230442. The content is solely the responsibility of the authors and does not necessarily represent the official views of the National Institutes of Health. 
medRxiv preprint doi: https://doi.org/10.1101/2022.02.18.22271190; this version posted February 21, 2022. The copyright holder for this preprint

(which was not certified by peer review) is the author/funder, who has granted medRxiv a license to display the preprint in perpetuity.

All rights reserved. No reuse allowed without permission.

\section{Radiomic Features Predicts Pancreatic Cancer......}

\section{Abbreviations}

$\mathrm{AUC}=$ area under the curve

$\mathrm{Cl}=$ confidence interval

$\mathrm{CT}=$ computerized tomography

DSC $=$ Dice similarity coefficient

NCA = neighborhood component analysis

NOD $=$ new onset diabetes

NPV = negative predictive value

KPSC $=$ Kaiser Permanente Southern California

SEER = Surveillance, Epidemiology, and End Results

ICD-10-CM = Tenth Revision of International Classification of Diseases, Clinical Modification

$\mathrm{PCA}=$ principal component analysis

PDAC $=$ pancreatic ductal adenocarcinoma

PPV = positive predictive value

QIF = quantitative imaging features

SVM = support vector machine

Conflict of Interest: The authors declare they have not conflict of interest for this study.

Manuscript Type: Original Investigation

Word count: Text 3,000 
medRxiv preprint doi: https://doi.org/10.1101/2022.02.18.22271190; this version posted February 21, 2022. The copyright holder for this preprint

(which was not certified by peer review) is the author/funder, who has granted medRxiv a license to display the preprint in perpetuity.

All rights reserved. No reuse allowed without permission.

Radiomic Features Predicts Pancreatic Cancer......

WHAT IS KNOWN

- Pancreatic cancer is the $3^{\text {rd }}$ leading cause of cancer deaths.

- Early detection of pancreatic ductal adenocarcinoma (PDAC) is difficult owing to lack of specific symptoms or established screening.

WHAT IS NEW HERE

- Quantitative imaging features (QIF) of pre-diagnostic CT scans can accurately predict PDAC in 3-36 months prior to diagnosis (accuracy $94-95 \%$ and AUC 0.98-0.99).

- QIF on CT examinations within 2-3 years prior to cancer diagnosis also had very high predictive accuracy (accuracy 95-98\%; AUC 0.99-1.00).

- The QIF-based algorithm outperformed manual re-review of images for determination of PDAC risk. 
medRxiv preprint doi: https://doi.org/10.1101/2022.02.18.22271190; this version posted February 21, 2022. The copyright holder for this preprint (which was not certified by peer review) is the author/funder, who has granted medRxiv a license to display the preprint in perpetuity. All rights reserved. No reuse allowed without permission.

Radiomic Features Predicts Pancreatic Cancer......

\section{ABSTRACT}

Objectives: Pancreatic cancer $(P C)$ is the $3^{\text {rd }}$ leading cause of cancer deaths. We aimed to detect early changes on computed tomography (CT) images associated with pancreatic ductal adenocarcinoma (PDAC) based on quantitative imaging features (QIF).

Methods: Adults 18+ years of age diagnosed with PDAC in 2008-2018 were identified. Their CT scans 3 months -3 years prior to the diagnosis date were matched to up to two scans of controls. Pancreas was automatically segmented using a previously developed algorithm. 111 QIF were extracted. The dataset was randomly split for training/validation. Neighborhood and principal component analyses were applied to select the most important features. Conditional support vector machine was used to develop prediction algorithms. The computer labels were compared with manually reviewed CT images 2-3 years prior to the index date in 19 cases and 19 controls.

Results: 227 scans from cases (stages: 35\% I-II, 44\% III-IV, 21\% unknown) and 554 matched scans of healthy controls were included (average age 71 years; $51 \%$ females). In the validation dataset, accuracy measures were 94\%-95\%, and area under the curve (AUC) measures were 0.98-0.99. Sensitivity, specificity, positive predictive value, and negative predictive values were in the ranges of $88-91 \%, 96-98 \%, 91-95 \%$, and $94-96 \%$. QIF on CT examinations within 2-3 years prior to index date also had very high predictive accuracy (accuracy 95-98\%; AUC 0.991.00). The QIF-based algorithm outperformed manual re-review of images for determination of PDAC-risk.

Conclusions: QIF can accurately predict PDAC on CT imaging and represent promising biomarkers for early detection of pancreatic cancer. 
medRxiv preprint doi: https://doi.org/10.1101/2022.02.18.22271190; this version posted February 21, 2022. The copyright holder for this preprint (which was not certified by peer review) is the author/funder, who has granted medRxiv a license to display the preprint in perpetuity. All rights reserved. No reuse allowed without permission.

Radiomic Features Predicts Pancreatic Cancer......

Keywords: pancreatic cancer; early detection; quantitative imaging features; radiomic analysis 
medRxiv preprint doi: https://doi.org/10.1101/2022.02.18.22271190; this version posted February 21, 2022. The copyright holder for this preprint (which was not certified by peer review) is the author/funder, who has granted medRxiv a license to display the preprint in perpetuity. All rights reserved. No reuse allowed without permission.

\section{Radiomic Features Predicts Pancreatic Cancer......}

\section{INTRODUCTION}

Pancreatic cancer is the third leading cause of cancer deaths in the United States with 48,220 estimated deaths in $2021 .^{1}$ The 5 -year survival in $2012-2017$ was only $10.8 \%{ }^{1}$ Pancreatic ductal adenocarcinoma (PDAC) is the most common form of pancreatic cancer accounting for up to $90 \%$ of all cases. Early detection of PDAC is difficult owing to lack of specific symptoms or established screening. As a result, nearly $50 \%$ of cases have distant metastases at the time of diagnosis. Given the challenges with early detection in PDAC, the Scientific Framework for PDAC issued by National Cancer Institute called for an evaluation of longitudinal screening protocols including imaging biomarkers for patients at high risk for PDAC. ${ }^{2}$

A key step for early detection is the ability to identify precursors of PDAC on conventional crosssectional imaging. Abnormalities of the pancreas such as main duct dilatation may be early indicators of PDAC and can be detected on computerized tomography (CT) with a high degree of reproducibility. ${ }^{3-5}$ However, these findings are often non-specific and improved methods are needed to identify accurate and reliable early indicators of pancreatic cancer on cross-sectional imaging.

Automated radiomic analysis of quantitative imaging features ${ }^{6}$ (QIF) abstracted directly from cross-sectional imaging offers a promising opportunity to objectively identify precursor findings related to pancreatic cancer. Radiomic analysis has been used to predict survival of PDAC patients $^{7-15}$,differentiate functional abdominal pain, recurrent acute pancreatitis, and chronic pancreatitis ${ }^{16}$, and distinguish autoimmune pancreatitis from PDAC. ${ }^{17}$ One study attempted to classify PDAC cases from normal pancreas based on QIF of CT images after cancer diagnosis; ${ }^{18}$ however, the ability to identify precursor lesions prior to cancer development remains a key step to early detection. A review including 70 studies concluded that "radiomics of 
medRxiv preprint doi: https://doi.org/10.1101/2022.02.18.22271190; this version posted February 21, 2022. The copyright holder for this preprint

(which was not certified by peer review) is the author/funder, who has granted medRxiv a license to display the preprint in perpetuity.

All rights reserved. No reuse allowed without permission.

\section{Radiomic Features Predicts Pancreatic Cancer......}

the pancreas holds promise as a quantitative imaging biomarker of both focal pancreatic lesions and diffuse changes of the pancreas". ${ }^{19}$ However, studies utilizing QIF to predict PDAC are limited.

The objective of the present study was to determine the ability of radiomics-based direct image analysis to identify changes in the pancreas on cross-sectional imaging associated with the subsequent development of pancreatic cancer. Specifically, we sought to develop automated computer algorithms to identify important QIF and subsequently assess performance for prediction of pancreatic PDAC overall and within time-specific intervals prior to development of cancer.

\section{METHODS}

\section{Study design and setting}

We conducted a nested case-control study, including cross-sectional abdominal CT images from health plan enrollees of Kaiser Permanente Southern California (KPSC). KPSC is an integrated healthcare system that provides comprehensive healthcare services for more than 4.8 million enrollees across 15 medical centers and 250+ medical offices throughout the Southern California region. KPSC health plan enrollees are broadly representative of the Southern California population at-large in terms of diversity with respect to race/ethnicity, socioeconomic status and other demographics. ${ }^{20}$ The study protocol was approved by the KPSC's Institutional Review Board.

\section{Eligible study subjects and CT scans}


medRxiv preprint doi: https://doi.org/10.1101/2022.02.18.22271190; this version posted February 21, 2022. The copyright holder for this preprint

(which was not certified by peer review) is the author/funder, who has granted medRxiv a license to display the preprint in perpetuity.

All rights reserved. No reuse allowed without permission.

\section{Radiomic Features Predicts Pancreatic Cancer......}

We identified adults 18+ years of age diagnosed with PDAC in 2008-2018 (index date, $\mathrm{t}_{0}$ ) based on the KPSC Cancer Registry by using the Tenth Revision of International Classification of Diseases, Clinical Modification (ICD-10-CM) code C25.x and histology codes listed in Supplemental Document 1. The KPSC Cancer Registry is a prospectively maintained registry and part of the Surveillance, Epidemiology, and End Results (SEER) reporting program. Patients with history of acute or chronic pancreatitis, history of pancreatectomy or did not have at least 12 months of health plan enrollment prior to $t_{0}$ were excluded (a gap of $\leq 45$ days was allowed). CT scans 3 months- 3 years prior to $t_{0}$ of the eligible PDAC cases were obtained and were matched to up to two scans of controls by age, gender, race/ethnicity, CT contrast status and year of scan ( \pm 2 years). Controls met the same eligibility criteria above but were pancreatic cancer free up to $t_{0}$ of the matched cases. All the CT scans were manually reviewed to remove those that did not capture the entire pancreas or had formatting errors. The resolution of scans was $512 \times 512$ pixels with slice thickness in the range of $2.5-5 \mathrm{~mm}$.

\section{Characteristics of study subjects}

Patient demographics, behavioral, and clinical characteristics on $t_{0}$ or in the 12 months prior to $t_{0}$ were extracted. Scan indications and the associated diagnosis for the visit were also captured. The tumor size was determined by manual review of radiology notes within the window of 3 months at the time of cancer diagnosis. The definitions of the clinical features are described in Supplemental Document 2.

\section{Pancreas segmentation}

The method to automatically extract the volumetric shape of the pancreas was previously described. ${ }^{21}$ When the same method was applied to the images of the current study, we started 
medRxiv preprint doi: https://doi.org/10.1101/2022.02.18.22271190; this version posted February 21, 2022. The copyright holder for this preprint

(which was not certified by peer review) is the author/funder, who has granted medRxiv a license to display the preprint in perpetuity.

All rights reserved. No reuse allowed without permission.

\section{Radiomic Features Predicts Pancreatic Cancer......}

from the estimated parameters previously derived and adjusted them to fit the data of the current study (see the method of enhancement in Supplemental Document 3). To evaluate the performance of the adjusted algorithm, we calculated Dice Similarity Coefficient (DSC) based on 9 randomly selected scans of PDAC cases by comparing the automated segmentation and that of manually delineated by the study radiologist (RP).

\section{Extraction of QIF}

First, we normalized center and width of intensity window of all the scans. 111 previously validated QIF 22 (Supplemental Document 4) were extracted from the segmented areas of pancreas using MATLAB software. ${ }^{23}$ Finally, the QIF were standardized such that they all had zero-mean and one standard deviation. ${ }^{24}$

\section{Algorithm development and validation}

\section{$\underline{\text { Preparation of training and validation datasets }}$}

The entire dataset was randomly split for training (50\%, DS1) and validation (50\%, DS2). DS2 was further divided into 5 subsets based on the temporal distance between the scan date and $t_{0}$ (or $t_{0}$ of the matched case): 3-6 months, 6 -12 months, 12-18 months, 18-24 months, and 24-36 months. By design, there is no overlap between training and validation datasets, and an individual scan was included in only one dataset.

\section{$\underline{\text { QIF selection method }}$}


medRxiv preprint doi: https://doi.org/10.1101/2022.02.18.22271190; this version posted February 21, 2022. The copyright holder for this preprint (which was not certified by peer review) is the author/funder, who has granted medRxiv a license to display the preprint in perpetuity. All rights reserved. No reuse allowed without permission.

\section{Radiomic Features Predicts Pancreatic Cancer......}

Two competing methods of feature selection were applied and compared based on DS1. The neighborhood component analysis (NCA) algorithm is a non-parametric method aiming for maximum prediction accuracy ${ }^{25,26}$. Using a regularization parameter $(\lambda)$, the process of NCA learns feature weights by minimizing the expected leave-one-out classification accuracy. To avoid over-fitting, we tuned the regulation parameter $\lambda$ based on 5 -fold cross validation. The $\lambda$ corresponding to the minimum classification loss was selected as the best. QIF with a weight greater than $2 \%$ of the maximum weight under the best $\lambda$ was deemed important ${ }^{26}$ In addition, we applied a second approach to feature collection: principal component analysis (PCA) to transform all 111 QIF into linear combinations that are orthogonal to one another. ${ }^{27}$ Principal components with eigenvalues $\geq 1$ were considered important. The analyses were performed by function fscnca in MATLAB ${ }^{28}$ and prcomp function in $\mathrm{R}^{29}$ respectively.

\section{Algorithm development}

Conditional support vector machine $(\mathrm{SVM})^{30}$ was applied to develop prediction algorithms based on DS1. The reason for using "conditional" SVM is to account for the paired structure of the matched data. More specifically, we centered the within pair data by its mean. ${ }^{30}$ For example, for a specific feature, the values were 0.4 and 0.6 , respectively, from the images of a case and one of his/her controls, the centered values became -0.1 and 0.1 . SVM is a high-performing non-linear classifier to map input data into higher dimensional space with the purpose of better ability of data separation ${ }^{31}$ Moreover, SVM can ignore outliers. The kernels functions used in the study included Gaussian, linear, and sigmoid. ${ }^{32,33}$ The two hyperparameters were tuned based on 5-fold cross-validation (Supplemental Document 5). 
medRxiv preprint doi: https://doi.org/10.1101/2022.02.18.22271190; this version posted February 21, 2022. The copyright holder for this preprint

(which was not certified by peer review) is the author/funder, who has granted medRxiv a license to display the preprint in perpetuity.

All rights reserved. No reuse allowed without permission.

\section{Radiomic Features Predicts Pancreatic Cancer......}

The performance of the prediction algorithms was evaluated using sensitivity, specificity, positive predictive value (PPV), negative predictive value (NPV), accuracy and area under curve $(A \cup C)$ based on DS2. Accuracy was defined as the total number of correctly predicted individuals divided by the total number of patients. The validation was performed using the entire validation dataset and repeated in each of the 5 validation subsets.

\section{Exploratory analyses}

Because the selection of QIF by NCA may vary largely from one dataset to another, we conducted exploratory analyses to understand how the instability of QIF selection may impact the performance of final prediction algorithms (Supplemental Document 6).

\section{Clinical evaluation}

A blind manual re-review of scans of $100 \%$ cases and $50 \%$ controls in the validation dataset 24 36 months prior to $t_{0}$ was performed by the study radiologist (RP) to determine the risk of PDAC. Patients were classified as low risk if they only had diffuse atrophy, smaller cyst, simple cyst, loss of normal lobulation, or mild diffuse duct dilatation/prominence, or did not have any obvious morphological features. Patients with complex cyst, cyst larger than $2 \mathrm{~cm}$, loss of normal lobulation of contour, or having two or more low risk features were considered having medium risk. Those with solid mass, focal abnormal enhancement, focal duct stricture, or focal/segmental atrophy were deemed high risk. The reviewer was not informed about the computer labels or case/control status at the time of review. The manual risk assessment was compared with the assigned computer labels (high risk " $50 \%+$ " vs. low risk " $<50 \%$ ") based on the prediction algorithm developed with Gaussian kernel function and PCA. 
medRxiv preprint doi: https://doi.org/10.1101/2022.02.18.22271190; this version posted February 21, 2022. The copyright holder for this preprint

(which was not certified by peer review) is the author/funder, who has granted medRxiv a license to display the preprint in perpetuity.

All rights reserved. No reuse allowed without permission.

\section{Radiomic Features Predicts Pancreatic Cancer......}

\section{Statistical analysis}

Characteristics of cases and controls were compared by using a conditional logistic regression model to account for the matched design. All the analyses were performed using SAS $^{34}$ except for the MATLAB or R packages ${ }^{35}$ mentioned previously.

\section{RESULTS}

\section{Characteristics of the Study Cohort}

The study included 277 scans of PDAC cases and 554 matching scans from controls (Figure 1). $35 \%$ cases were stages I-II, $7.6 \%$ stage III, $36.8 \%$ stage IV, and $21 \%$ stage unknown at the time of diagnosis (Table 1). The median tumor size was 3.3cm (IQR 2.4-4.2) in the 148 cases with known information. On the average, the patients were 70.8 years of age and $50.5 \%$ were women. $47.3 \%$ were non-Hispanic whites, $26.7 \%$ were Hispanic, $18.4 \%$ were African American, and $7.6 \%$ were Asian/Pacific Islanders (Table 1). Ever tobacco use was frequent in both cases $(57.1 \%)$ and in controls $(51.7 \%)(p=0.14)$. Family history of pancreatic cancer, and diabetes were more common in cases than in controls (Table 1). Body mass index and weight change in one year were comparable between cases and controls. Among specified scan indications and associated diagnosis for the visit, abdominal pain, other pain, and Gl problems appeared most frequent (Supplemental Document 7).

\section{Pancreas Segmentation}


medRxiv preprint doi: https://doi.org/10.1101/2022.02.18.22271190; this version posted February 21, 2022. The copyright holder for this preprint

(which was not certified by peer review) is the author/funder, who has granted medRxiv a license to display the preprint in perpetuity.

All rights reserved. No reuse allowed without permission.

\section{Radiomic Features Predicts Pancreatic Cancer......}

The average of DSC from the automated pancreas segmentation algorithm was 83.25 (range \pm

SD 5.19). Two example images with automated pancreas segmentation and manual group reference segmentation are presented in Figure 2.

\section{Model training and validation}

For NCA, 5 QIF were selected (Supplemental Document 8). For PCA, 19 principal components were formed (Supplemental Document 9). Tables $2 \mathrm{a}$ and $2 \mathrm{~b}$ show the performance measures of the prediction algorithms based on the QIF selected by NCA and the principal components formed by PCA, respectively.

\section{Performance based on entire scan window ( 3 mos- 3 yrs prior to $t_{0} 2$}

Accuracy/AUC based on DS2 were $94 \% / 0.98$ and 95\%/0.99, respectively, for prediction algorithms developed based on NCA and PCA, regardless of kernel functions applied.

Sensitivity, specificity, PPV, and NPV based on DS2 were in the ranges of $88-91 \%, 96-98 \%, 91-$ 95\%, and 94-96\%, varying slightly by QIF selection method (NCA vs. PCA) and kernel function used to develop the prediction algorithms. Algorithms developed based on PCA had better performance than those of NCA for all measures regardless of kernel functions applied.

\section{Performance based on 5 individual sub-time windows}

The performance within each of the time windows remained high for both NCA and PCA methods. For the PCA method, the lowest sensitivity, specificity, PPV, NPV, accuracy, and AUC were $82 \%, 93 \%, 87 \%, 91 \%, 93 \%$, and 0.97 , respectively. QIF within $2-3$ years prior to $t_{0}$ also had very high predictive power (accuracy 95-98\%; AUC 0.99-1.00).

\section{Exploratory Analyses}


medRxiv preprint doi: https://doi.org/10.1101/2022.02.18.22271190; this version posted February 21, 2022. The copyright holder for this preprint

(which was not certified by peer review) is the author/funder, who has granted medRxiv a license to display the preprint in perpetuity.

All rights reserved. No reuse allowed without permission.

\section{Radiomic Features Predicts Pancreatic Cancer......}

6 and 14 QIF were selected from EDS1 and EDS2, respectively (Supplemental Document 6, Tables S1 and S3). Five of the 6 QIF selected from EDS1 were in the list of QIF selected from EDS2. The performance measures between the two sets of selected QIF were similar (Supplemental Document 6, Tables S2 and S4). The performance measures between the two sets of data were comparable.

\section{Clinical evaluation}

In the 19 PDAC cases with pre-diagnostic images in 24-36 months, 14, 4 and 1 patients were classified as having low, medium, and high risk based on the manual review of the CT images, respectively (Table 3). Similarly, in the 19 matched controls, an overwhelming majority were believed to have low risk based on the manual review of the CT images (Table 3). However, the computer algorithms only mistakenly predicted one patient in cases and correctly classified all the controls.

\section{DISCUSSION}

In this study, we developed and validated automated computer algorithms to predict PDAC solely based on QIF of pre-diagnostic CT scans. Our results showed QIF of pre-diagnostic scans can accurately predict PDAC in 3-36 months prior to diagnosis. Interestingly, when the validation was stratified by timing of scan in relation to diagnosis, the performance seemed to be maintained in all the time periods examined prior to cancer diagnosis. The QIF-based algorithm had excellent ability to predict PDAC (sensitivity 95\%, specificity 100\%, PPV 100\%, NPV 97\%, accuracy $98 \%$ and AUC 100\%) based on scans from 24-36 months prior to cancer diagnosis. A manual assessment of the scans in 24-36 months prior to PDAC diagnosis revealed that an 
medRxiv preprint doi: https://doi.org/10.1101/2022.02.18.22271190; this version posted February 21, 2022. The copyright holder for this preprint

(which was not certified by peer review) is the author/funder, who has granted medRxiv a license to display the preprint in perpetuity.

All rights reserved. No reuse allowed without permission.

\section{Radiomic Features Predicts Pancreatic Cancer......}

overwhelming majority had low risk of PDAC, yet the computer algorithm was able to predict the outcome correctly except for one case who had mild ductal prominence and loss of lobulation in pancreas head.

A major barrier for early detection in pancreatic cancer is the inability to reliably identify precursor lesions based on conventional imaging. Pancreatic Intra-epithelial neoplasia (PanIN) III or high-grade dysplasia are histologic findings not typically visible on cross-sectional imaging $^{36}$. Previous studies have identified specific abnormalities that can be identified in up to $50 \%$ of cancer cases prior to diagnosis of PDAC including main duct dilatation, atrophy and duct stricture. 4,37,38 However, such findings lack sensitivity and in many cases are subject to interpreter variability. Therefore, a systematic approach of direct imaging analysis that applies objective assessment of imaging-based parameters provides a promising opportunity to identify imaging-based signatures of early pancreatic cancer. The performance of the algorithms was high in all the time windows being studied.

Radiomics has been applied in the diagnosis, prediction, and prognosis of other cancer types (e.g. lung cancer, lung nodule and breast cancer). ${ }^{39}$ While radiomics has been applied for prognosis in PDAC ${ }^{7-12}$, very little progress has been made with respect to early detection. Using 225 training and 125 validation images, Chu et al. differentiated CT scans of PDAC patients and healthy controls with a sensitivity of $100 \%$ and specificity $98.5 \% .{ }^{18}$ However, in Chu's study, the images being analyzed were taken after diagnosis (mean tumor size $4.1 \mathrm{~cm}$ ). In addition, the pancreas boundaries were manually segmented ${ }^{18}$ and thus, utility of the algorithm in clinical operation is limited. In the current study, pre-diagnostic scans were applied, and the segmentation of pancreas was computerized. 
medRxiv preprint doi: https://doi.org/10.1101/2022.02.18.22271190; this version posted February 21, 2022. The copyright holder for this preprint (which was not certified by peer review) is the author/funder, who has granted medRxiv a license to display the preprint in perpetuity. All rights reserved. No reuse allowed without permission.

\section{Radiomic Features Predicts Pancreatic Cancer......}

A key distinction related to assessment of pre-diagnostic imaging is whether the automated QIF algorithms were classifying cancer risk based on features readily visible on the images or incorporating additional elements from the data contained within the images. What we observed in the current study is that relying on human assessment of the pre-diagnostic CT images taken 2-3 years prior to cancer diagnosis by an expert body-image radiologist with 15 years of experience failed to distinguish cancer and healthy patients at the level of performance obtained by the radiomics-based algorithm suggesting the QIF provide additional information beyond identification of established radiographic findings.

The current study has several strengths. First, we implemented a pancreas segmentation algorithm and series of quantitative imaging features that were previously validated. Therefore, the developed classifiers can potentially be widely implemented across health care systems. Second, we relied on pre-diagnostic images 3 months-3 years prior to cancer diagnosis. Thus, the developed algorithms have the potential to predict pancreatic cancer in a time frame that would allow for sufficient lead-time for intervention to impact the disease course. Third, we applied two machine learning approaches to select the most influential radiomic features. Although both methods worked well, it appears that algorithms based on principal components formed by PCA are more accurate. This is likely to be the result of the more inclusive nature of PCA compared to NCA. Finally, the comparison between blinded expert human review and automated QIF-based algorithm helped to demonstrate the potential added-value of this approach beyond identification of established abnormalities of the pancreatic parenchymal or duct system.

The current study had several limitations. First, although the images being used in the analyses were at least 3 months prior to cancer diagnosis, a small number of scans may contain visible tumors, which may deform the shape of pancreas and thus negatively impact the performance of the final algorithms. A few $(<5)$ images were manually removed due to visible tumors. 
medRxiv preprint doi: https://doi.org/10.1101/2022.02.18.22271190; this version posted February 21, 2022. The copyright holder for this preprint (which was not certified by peer review) is the author/funder, who has granted medRxiv a license to display the preprint in perpetuity. All rights reserved. No reuse allowed without permission.

\section{Radiomic Features Predicts Pancreatic Cancer......}

However, additional images with visible tumors may still have been present. Second, when the weights of the convolutional neural network for pancreas segmentation derived previously were adjusted to fit the scans of the current study, the process was only applied to the scans of cases but not to the scans of controls. Third, we did not consider higher-order statistics QIF (e.g. Gabor wavelet transformation) in the study. Previously studies have shown that mapping QIF into a higher-order feature space can further improve accuracy. ${ }^{13,15}$ Fourth, cases and controls were not matched by the indications for the scans. Fifth, the manual assessment for PDAC risk was only performed for images in 2-3 years prior to the index date. Finally, the current study lacks an external validation, in which CT images from another health care may be used to test the robustness of our algorithms.

\section{CONCLUSION}

The radiomics-based automated algorithms provide a method to detect PDAC as early as 2-3 years prior to cancer diagnosis. The algorithm has the potential to be used for future early detection protocols for pancreatic cancer. Future studies are needed to understand feasibility, challenges, and cost-effectiveness of such an implementation. 
medRxiv preprint doi: https://doi.org/10.1101/2022.02.18.22271190; this version posted February 21, 2022. The copyright holder for this preprint (which was not certified by peer review) is the author/funder, who has granted medRxiv a license to display the preprint in perpetuity. All rights reserved. No reuse allowed without permission.

\section{Radiomic Features Predicts Pancreatic Cancer......}

\section{Figure Legend}

Figure 1. Consort diagram.

Figure 2. Two example images with automated pancreas segmentation (blue) and manual group truth segmentation (red). 
medRxiv preprint doi: https://doi.org/10.1101/2022.02.18.22271190; this version posted February 21, 2022. The copyright holder for this preprint (which was not certified by peer review) is the author/funder, who has granted medRxiv a license to display the preprint in perpetuity. All rights reserved. No reuse allowed without permission.

\section{Radiomic Features Predicts Pancreatic Cancer......}

\section{Acknowledgement}

The authors thank Sole Cardoso for the assistance with formatting the manuscript, and Botao

Zhou for the additional analyses. The images were kindly provided by the Medical Imaging

Technology and Informatics group of Kaiser Permanente Southern California Permanente

Medical Group. 
medRxiv preprint doi: https://doi.org/10.1101/2022.02.18.22271190; this version posted February 21, 2022. The copyright holder for this preprint

(which was not certified by peer review) is the author/funder, who has granted medRxiv a license to display the preprint in perpetuity.

All rights reserved. No reuse allowed without permission.

\section{Radiomic Features Predicts Pancreatic Cancer......}

\section{REFERENCES}

1. Health NIo. NIH Surveillance, Epidemiology, and End Results Program. US Department of Health and Human Services; National Institutes of Health; National Cancer Institute; 2021.

2. Health Nlo. Scientific Framework for Pancreatic Ductal Adenocarcinoma (PDAC). In: National Cancer Institute; 2014:1-29.

3. Tanaka S, Nakao M, loka T, et al. Slight dilatation of the main pancreatic duct and presence of pancreatic cysts as predictive signs of pancreatic cancer: a prospective study. Radiology. 2010;254(3):965-972.

4. Gangi S, Fletcher JG, Nathan MA, et al. Time interval between abnormalities seen on CT and the clinical diagnosis of pancreatic cancer: retrospective review of CT scans obtained before diagnosis. AJR American journal of roentgenology. 2004;182(4):897903.

5. Wu BU, Sampath K, Berberian CE, et al. Prediction of malignancy in cystic neoplasms of the pancreas: a population-based cohort study. The American journal of gastroenterology. 2014;109(1):121-129; quiz 130.

6. Gillies RJ, Kinahan PE, Hricak H. Radiomics: Images Are More than Pictures, They Are Data. Radiology. 2016;278(2):563-577.

7. Eilaghi A, Baig S, Zhang Y, et al. CT texture features are associated with overall survival in pancreatic ductal adenocarcinoma - a quantitative analysis. BMC medical imaging. 2017;17(1):38.

8. Cassinotto C, Chong J, Zogopoulos G, et al. Resectable pancreatic adenocarcinoma: Role of CT quantitative imaging biomarkers for predicting pathology and patient outcomes. European journal of radiology. 2017;90:152-158. 
medRxiv preprint doi: https://doi.org/10.1101/2022.02.18.22271190; this version posted February 21, 2022. The copyright holder for this preprint

(which was not certified by peer review) is the author/funder, who has granted medRxiv a license to display the preprint in perpetuity. All rights reserved. No reuse allowed without permission.

\section{Radiomic Features Predicts Pancreatic Cancer......}

9. Attiyeh MA, Chakraborty J, Doussot A, et al. Survival Prediction in Pancreatic Ductal Adenocarcinoma by Quantitative Computed Tomography Image Analysis. Annals of surgical oncology. 2018;25(4):1034-1042.

10. Chakraborty J, Langdon-Embry L, Cunanan KM, et al. Preliminary study of tumor heterogeneity in imaging predicts two year survival in pancreatic cancer patients. PloS one. 2017;12(12):e0188022.

11. Yun G, Kim YH, Lee YJ, Kim B, Hwang JH, Choi DJ. Tumor heterogeneity of pancreas head cancer assessed by CT texture analysis: association with survival outcomes after curative resection. Scientific reports. 2018;8(1):7226.

12. Sandrasegaran K, Lin $\mathrm{Y}$, Asare-Sawiri M, Taiyini T, Tann M. CT texture analysis of pancreatic cancer. European radiology. 2019;29(3):1067-1073.

13. Zhang Y, Lobo-Mueller EM, Karanicolas P, Gallinger S, Haider MA, Khalvati F. Improving prognostic performance in resectable pancreatic ductal adenocarcinoma using radiomics and deep learning features fusion in CT images. Scientific reports. 2021;11(1):1378.

14. Zhang Y, Lobo-Mueller EM, Karanicolas P, Gallinger S, Haider MA, Khalvati F. CNNbased survival model for pancreatic ductal adenocarcinoma in medical imaging. BMC medical imaging. 2020;20(1):11.

15. Khalvati F, Zhang Y, Baig S, et al. Prognostic Value of CT Radiomic Features in Resectable Pancreatic Ductal Adenocarcinoma. Scientific reports. 2019;9(1):5449.

16. Mashayekhi R, Parekh VS, Faghih M, Singh VK, Jacobs MA, Zaheer A. Radiomic features of the pancreas on CT imaging accurately differentiate functional abdominal pain, recurrent acute pancreatitis, and chronic pancreatitis. European journal of radiology. 2020;123:108778. 
medRxiv preprint doi: https://doi.org/10.1101/2022.02.18.22271190; this version posted February 21, 2022. The copyright holder for this preprint (which was not certified by peer review) is the author/funder, who has granted medRxiv a license to display the preprint in perpetuity. All rights reserved. No reuse allowed without permission.

\section{Radiomic Features Predicts Pancreatic Cancer......}

17. Park S, Chu LC, Hruban $\mathrm{RH}$, et al. Differentiating autoimmune pancreatitis from pancreatic ductal adenocarcinoma with CT radiomics features. Diagnostic and interventional imaging. 2020;101(9):555-564.

18. Chu LC, Park S, Kawamoto S, et al. Utility of CT Radiomics Features in Differentiation of Pancreatic Ductal Adenocarcinoma From Normal Pancreatic Tissue. AJR American journal of roentgenology. 2019;213(2):349-357.

19. Abunahel BM, Pontre B, Kumar H, Petrov MS. Pancreas image mining: a systematic review of radiomics. European radiology. 2021;31(5):3447-3467.

20. Koebnick C, Langer-Gould AM, Gould MK, et al. Sociodemographic characteristics of members of a large, integrated health care system: comparison with US Census Bureau data. The Permanente journal. 2012;16(3):37-41.

21. Asadpour V PR, Mayock RP,Sampson SE,Chen W,Wu BU. Pancreatic Cancer Tumor Analysis in CT Images using Patch-Based Multi-Resolution Convolutional Neural Network. Biomed Signal Process Control. 2021;In press.

22. Zwanenburg A, Vallières $M$, Abdalah MA, et al. The Image Biomarker Standardization Initiative: Standardized Quantitative Radiomics for High-Throughput Image-based Phenotyping. Radiology. 2020;295(2):328-338.

23. MathWorks. MATLAB Parallel Computing Toolbox ${ }^{\text {TM }}$ software In:2020.

24. Huo Y, Tang Y, Chen Y, et al. Stochastic tissue window normalization of deep learning on computed tomography. Journal of medical imaging (Bellingham, Wash). 2019;6(4):044005.

25. Goldberger J, Roweis S, Hinton G, Salakhutdinov R. Neighbourhood Components Analysis. In: Department of Computer Science UoT, ed. Canada2004.

26. Yang W, Wang K, Zuo W. Neighborhood Component Feature Selection for HighDimensional Data. J of Computers. 2012;7(1):161-168. 
medRxiv preprint doi: https://doi.org/10.1101/2022.02.18.22271190; this version posted February 21, 2022. The copyright holder for this preprint (which was not certified by peer review) is the author/funder, who has granted medRxiv a license to display the preprint in perpetuity. All rights reserved. No reuse allowed without permission.

Radiomic Features Predicts Pancreatic Cancer......

27. Rao CR. The Use and Interpretation of Principal Component Analysis in Applied Research. The Indian Journal of Statistics, Series A (1961-2002). 1964;26(4):329-358.

28. MathWorks. Statistics and Machine Learning Toolbox. 2021; https://www.mathworks.com/help/stats/neighborhood-component-analysis.html. .

29. R Core Team. R: A Language and Environment for Statistical Computing. 2017; https://www.R-project.org. Accessed Aug 11, 2021.

30. Stanfill B, Reehl S, Bramer L, et al. Extending Classification Algorithms to Case-Control Studies. Biomedical engineering and computational biology. 2019;10:1179597219858954.

31. Gunn SR. Support vector machines for classification and regression. 1998.

32. Souza CR. Kernel Functions for Machine Learning Applications. 2010; http://crsouza.com/2010/03/17/kernel-functions-for-machine-learning-applications/.

Accessed June 9, 2021.

33. Hofmann T, Scholkopf B, Smola A. Kernel Methods in Machine Learning. The Annals of Statistics. 2008;36(3):1171-1220.

34. SAS Version 9.4 for Unix; SAS Institute C, NC. SAS. 2021.

35. Software R. R software. Version 3.6.2; R software. Version 3.6.2, . 2021.

36. Basturk O, Hong SM, Wood LD, et al. A Revised Classification System and Recommendations From the Baltimore Consensus Meeting for Neoplastic Precursor Lesions in the Pancreas. Am J Surg Pathol. 2015;39(12):1730-1741.

37. Singh DP, Sheedy S, Goenka $\mathrm{AH}$, et al. Computerized tomography scan in prediagnostic pancreatic ductal adenocarcinoma: Stages of progression and potential benefits of early intervention: A retrospective study. Pancreatology : official journal of the International Association of Pancreatology (IAP) [et al]. 2020;20(7):1495-1501. 
medRxiv preprint doi: https://doi.org/10.1101/2022.02.18.22271190; this version posted February 21, 2022. The copyright holder for this preprint

(which was not certified by peer review) is the author/funder, who has granted medRxiv a license to display the preprint in perpetuity. All rights reserved. No reuse allowed without permission.

\section{Radiomic Features Predicts Pancreatic Cancer......}

38. Chen W, Butler RK, Zhou Y, Parker RA, Jeon CY, Wu BU. Prediction of Pancreatic Cancer Based on Imaging Features in Patients With Duct Abnormalities. Pancreas. 2020;49(3):413-419.

39. Gillies RJ, Schabath MB. Radiomics Improves Cancer Screening and Early Detection. Cancer epidemiology, biomarkers \& prevention : a publication of the American Association for Cancer Research, cosponsored by the American Society of Preventive Oncology. 2020;29(12):2556-2567. 
medRxiv preprint doi: https://doi.org/10.1101/2022.02.18.22271190; this version posted February 21, 2022. The copyright holder for this preprint (which was not certified by peer review) is the author/funder, who has granted medRxiv a license to display the preprint in perpetuity. All rights reserved. No reuse allowed without permission.

Radiomic Features Predicts Pancreatic Cancer......

Table 1. Characteristics of study subjects at baseline by case and control status, $\mathbf{n}(\%)$ unless otherwise stated.

\begin{tabular}{|c|c|c|c|}
\hline Patient characteristics & $\begin{array}{l}\text { Cases } \\
\mathrm{N}=277\end{array}$ & $\begin{array}{r}\text { Controls } \\
N=554\end{array}$ & p-value \\
\hline Age, mean (SD) & $70.8(10.33)$ & $70.8(10.32)$ & NA \\
\hline Female & $140(50.5 \%)$ & $280(50.5 \%)$ & NA \\
\hline Race/ethnicity & & & NA \\
\hline Non-Hispanic white & $131(47.3 \%)$ & $262(47.3 \%)$ & \\
\hline African American & $51(18.4 \%)$ & $102(18.4 \%)$ & \\
\hline Hispanic & $74(26.7 \%)$ & $148(26.7 \%)$ & \\
\hline Asian and Pacific Islanders & $21(7.6 \%)$ & $42(7.6 \%)$ & \\
\hline \multicolumn{4}{|l|}{ Insurances (mutually inclusive) } \\
\hline Commercial & $88(31.8 \%)$ & $179(32.3 \%)$ & 0.94 \\
\hline Medi-CAL & $9(3.2 \%)$ & $19(3.4 \%)$ & 0.89 \\
\hline Medicare & $185(66.8 \%)$ & $370(66.8 \%)$ & $>0.99$ \\
\hline Private pay & $104(37.5 \%)$ & $238(43 \%)$ & 0.12 \\
\hline Years of health plan enrollment, mean (SD) & $27.5(16.27)$ & $25.5(13.58)$ & 0.051 \\
\hline Less than high school education, geocoded & $18.1(14.04)$ & $17.3(13.34)$ & 0.65 \\
\hline Tobacco use & & & 0.14 \\
\hline Ever & $157(57.1 \%)$ & $286(51.7 \%)$ & \\
\hline Never & $118(42.9 \%)$ & $267(48.3 \%)$ & \\
\hline Unknown & $2(. \%)$ & $1(. \%)$ & \\
\hline Diagnosis of alcohol abuse in the past year & $13(4.7 \%)$ & $28(5.1 \%)$ & 0.91 \\
\hline Diagnosis of alcohol abuse any time in the past & $30(10.8 \%)$ & $51(9.2 \%)$ & 0.61 \\
\hline Family history of pancreatic cancer & $18(6.5 \%)$ & $5(0.9 \%)$ & $<.001$ \\
\hline BMI & & & 0.88 \\
\hline Underweight $(<18.5)$ & $7(2.5 \%)$ & $22(4 \%)$ & \\
\hline Normal weight (18.5-24.9) & $79(28.5 \%)$ & $166(30 \%)$ & \\
\hline Overweight (25-29.9) & $100(36.1 \%)$ & $187(33.8 \%)$ & \\
\hline Obese $(30+)$ & $86(31 \%)$ & $169(30.5 \%)$ & \\
\hline Unknown & $5(1.8 \%)$ & $10(1.8 \%)$ & \\
\hline Weight change in one year(kg) & & & 0.07 \\
\hline Median (IQR) & $-2.7(-5.4,0.9)$ & $-2.1(-4.5,1.5)$ & \\
\hline$\leq-6 \mathrm{~kg}$ & $50(18.1 \%)$ & $89(16.1 \%)$ & \\
\hline$>-6 \& \leq-4 \mathrm{~kg}$ & $23(8.3 \%)$ & $38(6.9 \%)$ & \\
\hline$>-4 \& \leq-2 \mathrm{~kg}$ & $34(12.3 \%)$ & $71(12.8 \%)$ & \\
\hline$>-2 \&<2 \mathrm{~kg}$ & 87 (31.4\%) & $167(30.1 \%)$ & \\
\hline$\geq 2 \&<4 \mathrm{~kg}$ & $22(7.9 \%)$ & $44(7.9 \%)$ & \\
\hline$\geq 4 \mathrm{~kg}$ & $14(5.1 \%)$ & $60(10.8 \%)$ & \\
\hline Unknown & $47(17 \%)$ & $85(15.3 \%)$ & \\
\hline Diabetes & $122(44 \%)$ & $191(34.5 \%)$ & 0.004 \\
\hline Biliary tract disease & $58(20.9 \%)$ & $114(20.6 \%)$ & 0.62 \\
\hline Depression & 87 (31.4\%) & $181(32.7 \%)$ & 0.78 \\
\hline Deep vein thrombosis & $9(3.2 \%)$ & $37(6.7 \%)$ & 0.08 \\
\hline Gallstone disorders & $47(17 \%)$ & $98(17.7 \%)$ & 0.89 \\
\hline Hereditary cancer syndromes & 37 (13.4\%) & $89(16.1 \%)$ & 0.35 \\
\hline Peptic ulcer & $5(1.8 \%)$ & $16(2.9 \%)$ & 0.25 \\
\hline \multicolumn{4}{|l|}{ Stage at diagnosis } \\
\hline 1 & $36(13.0 \%)$ & & \\
\hline
\end{tabular}


medRxiv preprint doi: https://doi.org/10.1101/2022.02.18.22271190; this version posted February 21, 2022. The copyright holder for this preprint (which was not certified by peer review) is the author/funder, who has granted medRxiv a license to display the preprint in perpetuity. All rights reserved. No reuse allowed without permission.

Radiomic Features Predicts Pancreatic Cancer......

II

III

IV

Unknown
$60(21.7 \%)$

$21(7.6 \%)$

$102(36.8 \%)$

$58(21.0 \%)$ 
Table 2. Performance of conditional SVM classifier with various kernel functions based on (a) the 5 features selected by NCA, and (b) the 19 principal components formed by PCA. Percent (\%) and $95 \%$ confidence interval $(\mathrm{Cl})$.

\section{(a)}

\begin{tabular}{|c|c|c|c|c|c|c|c|}
\hline Dataset & Kernel & Sensitivity (\%) & Specificity (\%) & PPV (\%) & NPV (\%) & Accuracy (\%) & AUC \\
\hline Training: DS1 & Gaussian & $97.1(94.3-99.9)$ & $98.6(97.1-100.0)$ & $97.1(94.3-99.9)$ & $98.6(97.1-100.0)$ & $98.1(96.7-99.4)$ & $0.998(0.993-1.000)$ \\
\hline [3 mos-3 yrs) & Linear & $94.9(91.3-98.6)$ & $97.1(95.1-99.1)$ & $94.2(90.4-98.1)$ & 97.5 (95.6-99.3) & $96.4(94.6-98.2)$ & $0.994(0.985-1.000)$ \\
\hline $\mathrm{N}=414$ & Sigmoid & $91.3(86.6-96.0)$ & $96.7(94.6-98.8)$ & $93.3(89.1-97.5)$ & 95.7 (93.3-98.1) & $94.9(92.8-97.0)$ & $0.983(0.967-0.998)$ \\
\hline Validation: DS2 & Gaussian & $89.2(84.1-94.4)$ & 95.7 (93.3-98.1) & $91.2(86.4-95.9)$ & $94.7(92.0-97.3)$ & $93.5(91.2-95.9)$ & $0.977(0.960-0.995)$ \\
\hline [3 mos-3 yrs) & Linear & $88.5(83.2-93.8)$ & $96.4(94.2-98.6)$ & $92.5(88.0-97.0)$ & $94.4(91.7-97.0)$ & $93.8(91.4-96.1)$ & $0.984(0.969-0.999)$ \\
\hline $\mathrm{N}=417$ & Sigmoid & 87.8 (82.3-93.2) & $97.5(95.6-99.3)$ & $94.6(90.7-98.5)$ & $94.1(91.4-96.8)$ & $94.2(92.0-96.5)$ & $0.978(0.960-0.995)$ \\
\hline Validation & Gaussian & 86.2 (73.7-98.8) & 87.9 (79.5-96.3) & $78.1(63.8-92.4)$ & 92.7 (85.9-99.6) & $87.4(80.4-94.3)$ & $0.955(0.900-1.000)$ \\
\hline [3-6 mos) & Linear & $89.7(78.6-100.0)$ & $93.1(86.6-99.6)$ & $86.7(74.5-98.8)$ & 94.7 (88.9-100.0) & $92.0(86.2-97.7)$ & $0.980(0.943-1.000)$ \\
\hline $\mathrm{N}=87$ & Sigmoid & $82.8(69.0-96.5)$ & $94.8(89.1-100.0)$ & $88.9(77.0-100.0)$ & $91.7(84.7-98.7)$ & $90.8(84.7-96.9)$ & $0.943(0.882-1.000)$ \\
\hline Validation & Gaussian & $91.2(\varepsilon$ & $0.0(10$ & $0.0(100.0-10$ & 95.8 (91.1-100.0) & $97.1(9$ & $0.980-1.000)$ \\
\hline$[6-12$ & Linear & 88.2 & $00.0(10$ & $100.0(100.0-10$ & 94.4 (89.2- & 96.1 & $-1.000)$ \\
\hline $\mathrm{N}=102$ & Sigmoid & $91.2(81$. & $98.5(95.7-100.0)$ & $96.9(90.8-100.0)$ & $95.7(91.0-100.0)$ & 2.3-99.8) & 80-1.000) \\
\hline Validation & Gaussian & $92.6(82.7-100.0)$ & $96.3(91.3-100.0)$ & $92.6(82.7-100.0)$ & $96.3(91.3-100.0)$ & $95.1(90.3-99.8)$ & $0.967(0.919-1.000)$ \\
\hline [12-18 mos) & Linear & $81.5(6$ & $94.4(88.3-100.0)$ & $88.0(75.3-100.0)$ & $91.1(83.6-98.5)$ & $3.6-96.6)$ & $0.973(0.928-1.000)$ \\
\hline $\mathrm{N}=81$ & Sigmoid & $88.9(77.0-100.0)$ & $96.3(91.3-100.0)$ & $92.3(82.1-100.0)$ & $94.5(88.5-100.0)$ & $93.8(88.6-99.1)$ & $0.976(0.935-1.000)$ \\
\hline $\begin{array}{l}\text { Validation } \\
\text { [18-24 mos) }\end{array}$ & $\begin{array}{l}\text { Gaussian } \\
\text { Linear }\end{array}$ & $\begin{array}{r}83.3(7) \\
90.0(7\end{array}$ & $\begin{array}{l}98.319 \\
96.7(9\end{array}$ & $\begin{array}{l}96.2(88.8-100.0) \\
93.1(83.9-100.0)\end{array}$ & $\begin{array}{r}92.2(85.6-98.8) \\
95.1(89.7-100.0)\end{array}$ & $\begin{array}{l}3.2-98.5) \\
.7-99.2)\end{array}$ & $\begin{array}{l}0.981(0.946-1.000) \\
0.974(0.934-1.000)\end{array}$ \\
\hline $\mathrm{N}=90$ & Sigmoid & $83.3(70.0-96.7)$ & $98.3(95.1-100.0)$ & $96.2(88.8-100.0)$ & $92.2(85.6-98.8)$ & $93.3(88.2-98.5)$ & $0.979(0.943-1.000)$ \\
\hline Valid & Gal & 0) & 0) & 90.0 & 0) & 4.7 & $1.000)$ \\
\hline$[24-3$ & Linea & $0.0)$ & $0.0)$ & t.7-100.0) & 97.4 & 96.5( & 30-1.000) \\
\hline $\mathrm{N}=57$ & Sigmoid & $94.7(84.7-100.0)$ & $100(100.0-100.0)$ & $00.0(100.0-100.0)$ & $97.4(92.5-100.0)$ & $98.2(94.8-100.0)$ & $0.997(0.980-1.000)$ \\
\hline \multicolumn{8}{|l|}{ (b) } \\
\hline Dataset & Kernel & Sensitivity (\%) & Specificity (\%) & PPV (\%) & NPV (\%) & Accuracy (\%) & AUC \\
\hline $\begin{array}{l}\text { Training: DS1 } \\
\text { [3 mos-3 yrs) }\end{array}$ & $\begin{array}{l}\text { Gaussian } \\
\text { Linear }\end{array}$ & $\begin{array}{l}96.4(93.3-99.5) \\
96.4(93.3-99.5)\end{array}$ & $\begin{array}{r}98.9(97.7-100.0) \\
98.2(96.6-99.8)\end{array}$ & $\begin{array}{r}97.8(95.3-100.0) \\
96.4(93.3-99.5)\end{array}$ & $\begin{array}{l}98.2(96.6-99.8) \\
98.2(96.6-99.8)\end{array}$ & $\begin{array}{l}98.1(96.7-99.4) \\
97.6(96.1-99.1)\end{array}$ & $\begin{array}{l}38-1.000) \\
38-1.000)\end{array}$ \\
\hline $\mathrm{N}=414$ & Sigmoid & $94.9(91.3-98.6)$ & $98.2(96.6-99.8)$ & $96.3(93.2-99.5)$ & $97.5(95.6-99.3)$ & $97.1(95.5-98.7)$ & $0.995(0.988-1.000)$ \\
\hline $\begin{array}{l}\text { Validation: DS2 } \\
\text { [3 mos-3 yrs) }\end{array}$ & $\begin{array}{l}\text { Gaussian } \\
\text { Linear }\end{array}$ & $\begin{array}{l}89.9(84.9-94.9) \\
91.4(86.7-96.0)\end{array}$ & $\begin{array}{l}97.5(95.6-99.3) \\
97.5(95.6-99.3)\end{array}$ & $\begin{array}{l}94.7(90.9-98.5) \\
94.8(91.0-98.5)\end{array}$ & $\begin{array}{l}95.1(92.6-97.6) \\
95.8(93.4-98.1)\end{array}$ & $\begin{array}{l}95.0(92.9-97.1) \\
95.4(93.4-97.4)\end{array}$ & $\begin{array}{l}0.988(0.975-1.000) \\
0.987(0.973-1.000)\end{array}$ \\
\hline $\mathrm{N}=417$ & Sigmoid & $89.2(84.1-94.4)$ & $97.8(96.1-99.5)$ & $95.4(91.8-99.0)$ & $94.8(92.2-97.3)$ & $95.0(92.9-97.1)$ & $0.986(0.972-1.000)$ \\
\hline Validation & Gaussian & $93.1(83.9-100.0)$ & 94.8 (89.1-100.0) & $90.0(79.3-100.0)$ & $96.5(91.7-100.0)$ & $94.3(89.4-99.1)$ & $0.974(0.932-1.000)$ \\
\hline [3-6 mos) & Linear & $93.1(83.9-100.0)$ & $93.1(86.6-99.6)$ & 87.1 (75.3-98.9) & 96.4 (91.6-100.0) & $93.1(87.8-98.4)$ & $0.976(0.935-1.000)$ \\
\hline
\end{tabular}


Radiomic Features Predicts Pancreatic Cancer......

\begin{tabular}{llrrrrrr}
$\mathrm{N}=87$ & Sigmoid & $93.1(83.9-100.0)$ & $94.8(89.1-100.0)$ & $90.0(79.3-100.0)$ & $96.5(91.7-100.0)$ & $94.3(89.4-99.1)$ & $0.973(0.930-1.000)$ \\
\hline Validation & Gaussian & $94.1(86.2-100.0)$ & $97.1(93.0-100.0)$ & $94.1(86.2-100.0)$ & $97.1(93.0-100.0)$ & $96.1(92.3-99.8)$ & $0.994(0.974-1.000)$ \\
{$[6-12$ mos $)$} & Linear & $97.1(91.4-100.0)$ & $98.5(95.7-100.0)$ & $97.1(91.4-100.0)$ & $98.5(95.7-100.0)$ & $98.0(95.3-100.0)$ & $0.993(0.972-1.000)$ \\
$\mathrm{N}=102$ & Sigmoid & $97.1(91.4-100.0)$ & $98.5(95.7-100.0)$ & $97.1(91.4-100.0)$ & $98.5(95.7-100.0)$ & $98.0(95.3-100.0)$ & $0.992(0.971-1.000)$ \\
\hline Validation & Gaussian & $85.2(71.8-98.6)$ & $98.1(94.6-100.0)$ & $95.8(87.8-100.0)$ & $93.0(86.4-99.6)$ & $93.8(88.6-99.1)$ & $0.979(0.941-1.000)$ \\
{$[12-18$ mos) } & Linear & $81.5(66.8-96.1)$ & $98.1(94.6-100.0)$ & $95.7(87.3-100.0)$ & $91.4(84.2-98.6)$ & $92.6(86.9-98.3)$ & $0.980(0.942-1.000)$ \\
$\mathrm{N}=81$ & Sigmoid & $81.5(66.8-96.1)$ & $98.1(94.6-100.0)$ & $95.7(87.3-100.0)$ & $91.4(84.2-98.6)$ & $92.6(86.9-98.3)$ & $0.979(0.941-1.000)$ \\
\hline Validation & Gaussian & $83.3(70.0-96.7)$ & $98.3(95.1-100.0)$ & $96.2(88.8-100.0)$ & $92.2(85.6-98.8)$ & $93.3(88.2-98.5)$ & $0.992(0.968-1.000)$ \\
{$[18-24$ mos) } & Linear & $90.0(79.3-100.0)$ & $98.3(95.1-100.0)$ & $96.4(89.6-100.0)$ & $95.2(89.8-100.0)$ & $95.6(91.3-99.8)$ & $0.988(0.961-1.000)$ \\
$\mathrm{N}=90$ & Sigmoid & $80.0(65.7-94.3)$ & $98.3(95.1-100.0)$ & $96.0(88.3-100.0)$ & $90.8(83.7-97.8)$ & $92.2(86.7-97.8)$ & $0.989(0.963-1.000)$ \\
\hline Validation & Gaussian & $94.7(84.7-100.0)$ & $100.0(100.0-100.0)$ & $100.0(100.0-100.0)$ & $97.4(92.5-100.0)$ & $98.2(94.8-100.0)$ & $0.999(0.987-1.000)$ \\
{$[24-36$ mos) } & Linear & $94.7(84.7-100.0)$ & $100.0(100.0-100.0)$ & $100.0(100.0-100.0)$ & $97.4(92.5-100.0)$ & $98.2(94.8-100.0)$ & $0.999(0.987-1.000)$ \\
$\mathrm{N}=57$ & Sigmoid & $94.7(84.7-100.0)$ & $100.0(100.0-100.0)$ & $100.0(100.0-100.0)$ & $97.4(92.5-100.0)$ & $98.2(94.8-100.0)$ & $0.999(0.987-1.000)$ \\
\hline
\end{tabular}

SVM: support vector machine; PCA: principal component analysis; PPV: positive predictive value; NPV: negative predictive value; AUC: area under curve. 
medRxiv preprint doi: https://doi.org/10.1101/2022.02.18.22271190; this version posted February 21, 2022. The copyright holder for this preprint (which was not certified by peer review) is the author/funder, who has granted medRxiv a license to display the preprint in perpetuity. All rights reserved. No reuse allowed without permission.

\section{Radiomic Features Predicts Pancreatic Cancer......}

Table 3. A blind ${ }^{\mathrm{a}}$ manual review of pre-diagnostic CT images in 24-36 months prior to PDAC diagnosis and the $\mathrm{CT}$ images of the matched controls by case-control status and compute labels (high risk vs. low risk) ${ }^{\mathrm{b}}$.

\begin{tabular}{|l|c|c|c|c|c|c|}
\hline \multirow{2}{*}{$\begin{array}{l}\text { Manually } \\
\text { assigned } \\
\text { of PDAC }\end{array}$} & \multicolumn{3}{|c|}{ Cases $(\mathrm{n}=19)$} & \multicolumn{3}{c|}{ Controls (n=19) } \\
\cline { 2 - 7 } & $\begin{array}{l}\text { Labeled by } \\
\text { computer as } \\
\text { having high } \\
\text { risk }(\mathrm{n}=18)\end{array}$ & $\begin{array}{l}\text { Labeled by } \\
\text { computer as } \\
\text { having low } \\
\text { risk }(\mathrm{n}=1)\end{array}$ & Total & $\begin{array}{l}\text { Labeled by } \\
\text { computer as } \\
\text { having high } \\
\text { risk }(\mathrm{n}=0)\end{array}$ & $\begin{array}{l}\text { Labeled by } \\
\text { computer as } \\
\text { having low } \\
\text { risk }(\mathrm{n}=19)\end{array}$ & Total \\
\hline Low & 14 & 0 & 14 & 0 & 16 & 16 \\
\hline Median & 3 & 1 & 4 & 0 & 2 & 2 \\
\hline High & 1 & 0 & 1 & 0 & 0 & 0 \\
\hline Non-diagnostic & 0 & 0 & 0 & 0 & 1 & 1 \\
\hline
\end{tabular}

a: Reviewer was not informed about the computer labels or PDAC case/control status at the time of review.

b: Computer label was assigned according to the prediction algorithm developed with Gaussian kernel function and principal component analysis.

c: Patients were classified as have low risk if they only had diffuse atrophy, smaller cyst, simple cyst, loss of normal lobulation, or mild diffuse duct dilatation/prominence, or did not have any obvious morphological features. Patients with complex cyst, cyst larger than $2 \mathrm{~cm}$, or loss of normal lobulation of contour, or having two or more low risk features were considered having medium risk. Those with solid mass, focal abnormal enhancement, focal duct stricture, or focal/segmental atrophy were deemed high risk. 
medRxiv preprint doi: https://doi.org/10.1101/2022.02.18.22271190; this version posted February 21, 2022. The copyright holder for this preprint

(which was not certified by peer review) is the author/funder, who has granted medRxiv a license to display the preprint in perpetuity.

All rights reserved. No reuse allowed without permission.

\section{Figure 1. Consort diagram}

CT scans for PDAC patients diagnosed in 2008-2018

3,930 patients // 15,227 scans

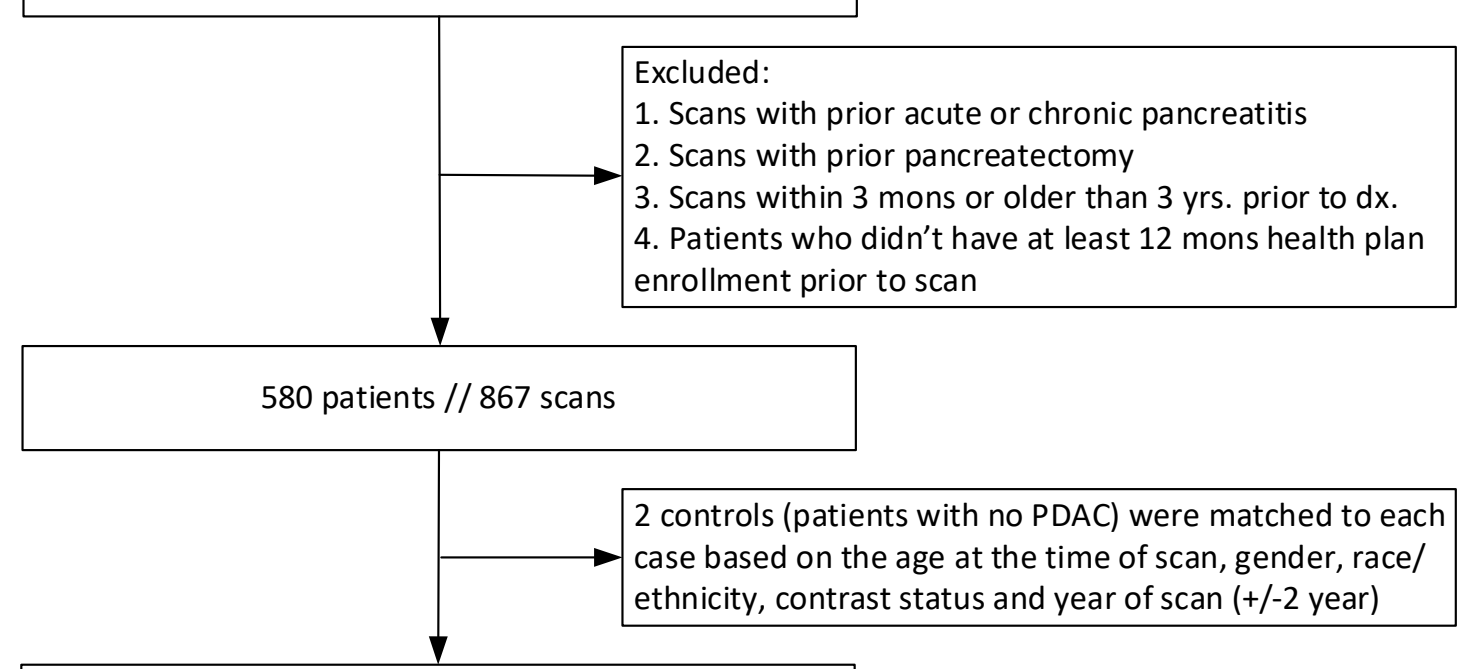

715 scans of cases matched to 1430 scans of controls

Randomly selected 296 scans of cases matched to 594 scans of controls

$\longrightarrow \begin{aligned} & \text { Excluded: } \\ & \text { 1. Entire scan if the number of slices }<20 \\ & \text { 2. Slices that had formatting errors } \\ & \text { 3. Slides not covering entire pancreas }\end{aligned}$

277 scans (belonging to 275 cases) matched to 554 scans (belonging to 541 controls) 
medRxiv preprint doi: https://doi.org/10.1101/2022.02.18.22271190; this version posted February 21, 2022. The copyright holder for this preprint (which was not certified by peer review) is the author/funder, who has granted medRxiv a license to display the preprint in perpetuity.

All rights reserved. No reuse allowed without permission.

Figure 2. Two example images with automated pancreas segmentation (blue) and manual group truth segmentation (red).

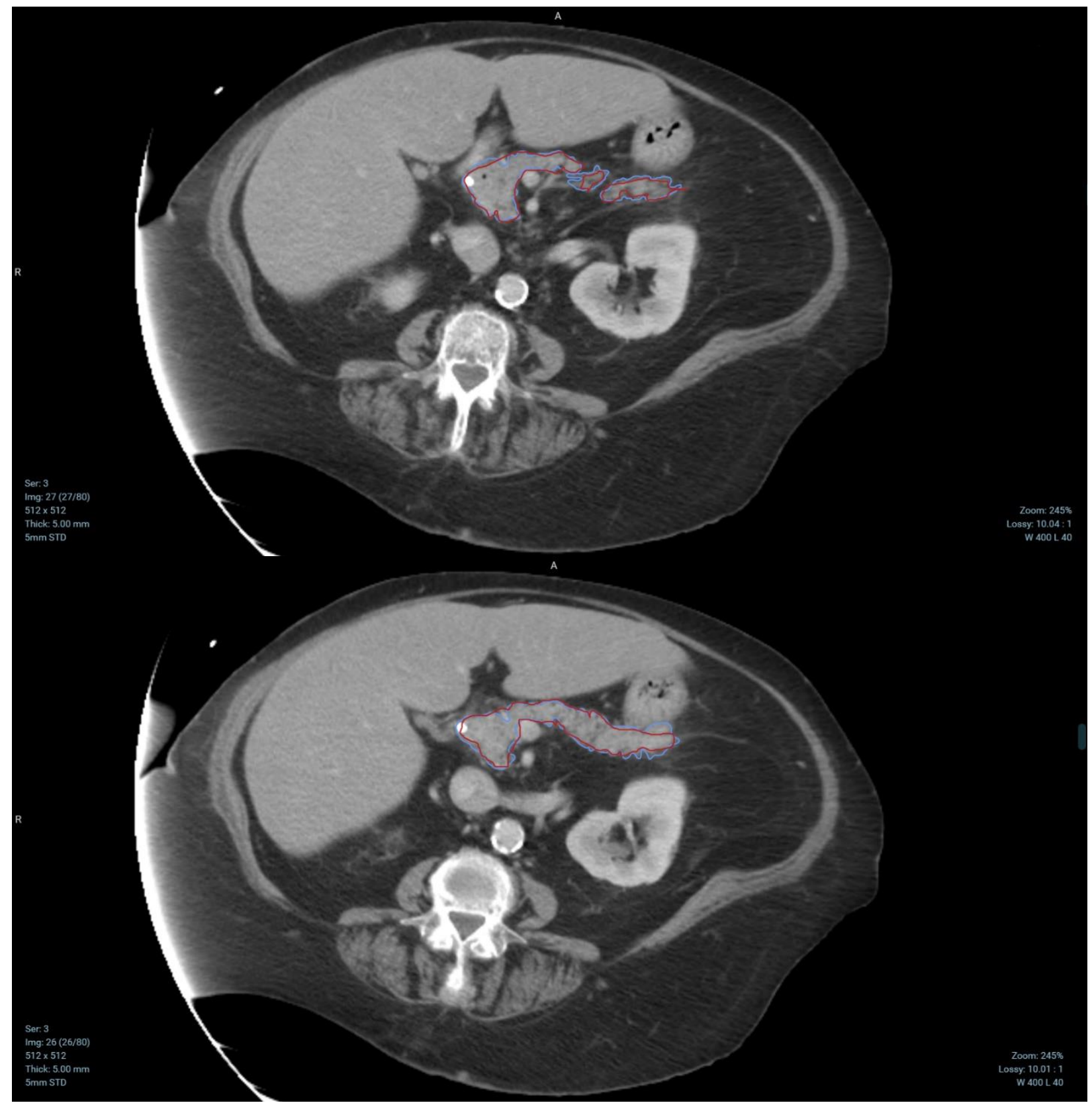

